University of Nebraska - Lincoln

DigitalCommons@University of Nebraska - Lincoln

\title{
How well do U.S. western water markets convey economic information
}

\author{
R. Rimsaite \\ University of Nebraska - Lincoln \\ K. Fisher-Vanden \\ S. Olmstead \\ D. Grogan
}

Follow this and additional works at: https://digitalcommons.unl.edu/natrespapers

Digitadrt of the Natural Resources and Conservation Commons, Natural Resources Management and Pommegrnmons, and the Other Environmental Sciences Commons

Network

Rimsaite, R.; Fisher-Vanden, K.; Olmstead, S.; and Grogan, D., "How well do U.S. western water markets convey economic information" (2021). Papers in Natural Resources. 1404.

https://digitalcommons.unl.edu/natrespapers/1404

This Article is brought to you for free and open access by the Natural Resources, School of at DigitalCommons@University of Nebraska - Lincoln. It has been accepted for inclusion in Papers in Natural Resources by an authorized administrator of DigitalCommons@University of Nebraska - Lincoln. 


\title{
How well do U.S. western water markets convey economic information?
}

\author{
Renata Rimsaite, Karen Fisher-Vanden, Sheila Olmstead, and Danielle Grogan*
}

January 2020

\begin{abstract}
An efficient market implies that potential gains from trade are fully captured. Achieving this requires a well-functioning market where prices reflect all available information. In the case of water rights markets, this implies that the permanent water rights transfer price reflects the sum of discounted returns to this asset (i.e., the lease price), the market interest rate, and a risk premium that reflects potential future water scarcity. The purpose of this study is to assess the efficiency of western U.S. water rights markets by utilizing the asset pricing model to measure how well prices reflect long-run returns to permanent water rights.
\end{abstract}

Keywords: water markets, water leases, water transfers, asset pricing model

*Rimsaite is a Post-doctoral scholar at Robert B. Daugherty Water for Food Global Institute and National Drought Mitigation Center at University of Nebraska - Lincoln. Fisher-Vanden is a Professor of Environmental and Resource Economics at Pennsylvania State University. Olmstead is a Professor at the LBJ School of Public Affairs at the University of Texas at Austin, a University Fellow at Resources for the Future, and a Senior Fellow at the Property and Environment Research Center. Grogan is a Research scientist at the Institute for the Study of Earth, Oceans, and Space at the University of New Hampshire.

Acknowledgments: This work was supported by the U.S. Department of Energy, Office of Science, Biological and Environmental Research Program, Earth and Environmental Systems Modeling, MultiSector Dynamics, Contract No. DE-SC0016162. 


\section{Introduction}

The number and scale of environmental markets have increased over time with successes in programs such as air pollution permit trading (Schmalensee and Stavins 2017) and individual transferable quota systems for fisheries (Costello, Gaines and Lynham 2008). However, even well-functioning environmental markets often fail to achieve their maximum theoretical advantage over other allocation or regulation mechanisms (Teitenberg 1990, Keohane 2007). The achieved efficiency gains from markets for natural resource assets have also been highly variable. Markets for fishing quota appear to be quite successful in this regard (Grainger and Costello 2011); those for wetland and habitat preservation, less so (National Research Council 2001, Parkhurst and Shogren 2003).

This paper examines markets for scarce water, advocated by economists for many decades (Hartman and Seastone 1970, Vaux and Howitt 1984, Saliba and Bush 1987). While informal water markets are common in some developing countries (Bjornlund and McKay 2002), formal inter-sectoral water markets have been slow to develop (Easter et al. 1999) and are generally immature (Carey, Sunding and Zilberman 2002; Brewer et al. 2008), making empirical studies of actual water markets uncommon. Nonetheless, studies have demonstrated potential and realized net benefits from trading in California (Hagerty 2019, Bruno and Jessoe 2019), south Texas (Chang and Griffin 1992), southern Italy and Spain (Pujol, Raggi, and Viaggi 2006; Rey, Garrido, and Calatrava 2014), north-central Chile (Hearne and Easter 1997, Hearne and Donoso 2014), Morocco (Diao and Roe 2003), and Australia (Bjornlund and McKay 2002, Tisdell 2014, Wheeler, Bjornlund, and Loch 2014, Zuo et al. 2015, Grafton, Horne, and Wheeler 2016, Loch, Wheeler, and Settre 2018). Australia's water markets may be especially relevant to western U.S. water markets given that a number of regions in the western U.S. are following the 
Australian case in the design of their water markets (e.g., Nevada's Diamond Valley and Humboldt Basin; Young 2015, Zeff et al. 2019, Wheeler et al. 2017).

U.S. water market efficiency (or the lack thereof) has been examined in the prior literature. ${ }^{1}$ Brookshire et al. (2004) and Brewer et al. (2008) suggest that U.S. western water markets are becoming more efficient and that water is moving from lower-valued (agricultural) to higher-valued (urban and environmental) uses. But some current water rights transfers in the United States are informal, and even active markets may exhibit high transaction costs (Scott and Coustalin 1995; Huffaker 2005; Rosegrant, Ringler, and Zhu 2014; Wheeler, Bjornlund, and Loch 2014; Hagerty 2019).

Market efficiency requires that prices reflect available information about scarcity and value in use. Therefore, an important area of study — which has been largely missing in the water market literature - is the role of pricing mechanisms in water rights markets. The purpose of this study is to assess the efficiency of western U.S. water rights markets by utilizing the asset pricing model to measure how well prices reflect long-run returns to permanent water rights. We exploit the variation in prices and quantities for water trades in the western United States between 1990 and 2010 to assess water markets' capacity to incorporate available information about long-run returns.

We apply the financial asset pricing model—similar to Newell, Sanchirico, and Kerr (2005) and Newell, Papps, and Sanchirico (2007) in their applications to New Zealand fishing quota markets - to U.S. water rights markets, econometrically estimating a water transfer price

\footnotetext{
${ }^{1}$ Note that truly efficient markets would also fully address externalities and public goods, important considerations in the context of water markets (Olmstead 2010). Our analysis does not consider these potential market failures, and instead focuses on the capacity of water market prices to transmit information about the private benefits and costs of water use. Finding that water markets do have this capacity would be a necessary, but not a sufficient condition to support their use (through taxation or other means) to address market failures.
} 
equation for nine western U.S. states for which the requisite data are available. The asset pricing model specifies the structural relationship between the permanent transfer price (i.e., the asset price) and the lease price (i.e., returns to the asset), the market interest rate, and a risk premium. Estimating an empirical specification of the asset pricing model (following Newell et al. 2007) allows us to assess the extent to which permanent transfer prices are influenced by these three factors, with a central focus on the lease price - the greater the influence of lease price on permanent transfer price (controlling for the market interest rate and water scarcity (a measure of risk)), the more efficient the market is.

To our knowledge, the asset pricing model has not been applied to water markets. ${ }^{2}$ Despite the small number of observations in our analysis, results suggest that water transfer prices are positively correlated with lease prices and negatively correlated with interest rates, as asset pricing theory would predict. These results are somewhat surprising. Though Newell, Papps, and Sanchirico (2007) find that prices in markets for fishing quota comport with the asset pricing model, these markets in New Zealand fisheries may be the most well-functioning created markets for natural assets (Grainger and Costello 2014). In water rights markets where prices are less stable and more heterogeneous, transaction costs are high, and trading is thin, it would not be surprising to find that the data were inconsistent with the asset pricing model (Yoskowitz 1999, Edwards and Libecap 2015).

Recognizing that our data include heterogeneous water markets in nine states, we extend our analysis to examine whether water market prices convey economic information more efficiently in relatively better-functioning markets. We apply the asset pricing model to a small regional market (the Mojave Basin area in California), where water transfers and leases represent

\footnotetext{
${ }^{2}$ Asset pricing models have also been applied to natural resource markets such as those for agricultural land (Alston 1986) and dairy quota (Wilson and Sumner 2004), in addition to fishing quota markets.
} 
trades in more homogeneous goods, trading is more active and better-monitored, and transaction costs are likely much lower than in the general case we assess in our multi-state analysis. The asset pricing results for the Mojave basin trades are stronger than those in our nine-state model, and stronger yet when we focus on the most active regions of that market. These results provide reason for optimism about water markets, should barriers to efficient trading be reduced in the future.

The paper is organized as follows. In section 2 we present the asset pricing model in theoretical and empirical formats. Section 3 discusses the multi-state sample transactions, data used in the multi-state asset pricing model application, and results. Section 4 presents the asset pricing model application to the Mojave market, including data and results. Conclusions are provided in section 5 .

\section{Asset pricing Theory and Empirical Models}

One implication of rational pricing theory for water market transactions is that the present value of permanent water rights should equal the discounted value of all future expected earnings from annual water leases. With constant lease prices and a constant growth rate, the price of a permanent water right would be as in equation (1), where the interest rate $(r)$ is equal to the expected annual rate of return from holding a water right.

$$
p^{\text {sale }}=\frac{p^{\text {lease }}}{r}
$$

Similar to Newell, Papps, and Sanchirico (2007), who apply the present value asset pricing model to examine the relationship between fishing quota asset and lease prices, we use the Gordon growth model (Campbell, Lo, and MacKinlay 1997), as shown in equation (2), and modify it to conform to the water rights market context. 


$$
p_{t}=\frac{\pi_{t}}{r_{t}-g}
$$

In equation (2), $p_{t}$ is the asset price, in our case the permanent water rights transfer price in period $t ; \pi$ is the future annual return from the asset - i.e., the one-year lease price; $r$ is the interest rate, and $g$ is a constant, asset-specific growth rate.

Water rights markets should be affected by future expectations about the value of water, influenced by expected climate conditions and institutional settings. Therefore, as suggested by Alston (1986), Cochrane (1992), and Newell, Papps, and Sanchirico (2007), we decompose $r$ into a real market interest rate $(\tilde{r})$ and a risk premium $(\theta)$, which in our water market case accounts for future water supply uncertainty. ${ }^{3}$ The variables used to represent each of these parameters in the theoretical model are described further in Section 3. Equation (3) provides the final form of our asset pricing model.

$$
p_{t}=\frac{\pi_{t}}{\tilde{r}_{t}+\theta_{t}-g}
$$

We empirically estimate the asset pricing model using data from nine western U.S. states where permanent transfers and one-year leases are both prevalent. However, even within a state, regional markets vary; for example, from large federal projects like the Colorado-Big Thompson (C-BT) project in Colorado or the Central Valley project (CVP) in California, to bilateral transactions between two neighboring farmers. Thus, as a second test of the asset pricing model, we also use a unique dataset from a single water market known to be relatively well-developed and active, located in the Mojave River Basin, in San Bernardino County, California. We repeat our empirical tests from the nine-state model on the Mojave River Basin market.

\footnotetext{
${ }^{3}$ Ideally, the risk premium would be specific to a particular water right and address both institutional uncertainty and climate uncertainty. Another approach would be to add a multiplicative function that includes factors related to uncertainty about the future to the growth model (Newell, Papps, and Sanchirico 2007). However, due to the small number of observations in our empirical analysis, this approach is not possible.
} 
As in Newell, Papps, and Sanchirico (2007), in our reduced-form empirical tests of the asset pricing model in both contexts, we regress water transaction prices on a set of explanatory variables as in equation (4),

$$
\ln p_{i j q t}=\gamma_{0}+\gamma_{1} \ln \pi_{i j q t}+\gamma_{2} \tilde{r}_{t}+\gamma_{3} \theta_{j}+\gamma_{4} g_{j}+\gamma_{5} \mu_{t}+\alpha_{j}+\varepsilon_{i j q t}
$$

where $\ln p$ is the $\log$ price of permanent water rights transfer $i$, in state $j$, in quarter $q$, and in year $t ; \ln \pi$ is the $\log$ price for a one-year lease; $\tilde{r}$ is the annual real U.S. market interest rate; $\theta$ is a risk premium; $g$ is the growth rate; $\mu$ is linear time trend; $\alpha$ is a state fixed effect or random effect; and $\varepsilon$ is the error term. In Section 3, we describe the variables used for $\tilde{r}, \theta$, and $g$. In well-functioning markets, prices of permanent transfers and leases may be determined simultaneously, so we estimate alternative models in which we instrument for own-state lease prices using the annual average lease price in all states except the state where a transaction takes

place. From the asset pricing theory discussed above, we expect $\gamma_{1}>0$, and $\gamma_{2}<0$. The expected signs of $\gamma_{3}$ and $\gamma_{4}$ will depend on the variables used to proxy for $\theta$ and $g$. Generally, a riskier asset should have a lower price and one with a higher long-term growth rate in expected profits should have a higher price, all else equal.

\section{Multi-state sample data and asset pricing model estimation}

\subsection{Water transaction data}

For the dependent variable in the multi-state asset pricing analysis, we purchased water market transactions data (permanent water transfers and one-year leases) from Stratecon, Inc. The data come from monthly issues of an industry publication, Water Strategist (Smith and Vaughan 
1990-94, 1995-2001; Smith 2002-2010), which has been previously described and analyzed in the literature (Howe and Goemans 2003; Brookshire et al. 2004; Howitt and Hansen 2005; Brown 2006; Brewer et al. 2008; Basta and Colby (2010), Libecap (2010), Colby et al. (2011), Grafton et al.(2012), Hansen et al. (2013), Goemans and Pritchet (2014), Hansen et al. (2014), Olmstead et al. (2016)). ${ }^{4}$ We omit observations associated with transactions that are outside the scope of our study; e.g., those involving recycled wastewater effluent, water storage rights, and multi-year leases as well as those with missing or unreasonable prices (less than $\$ 1$ per acrefoot), or unidentified buyers. Additionally, while market transactions from 12 states appear in the Water Strategist data, we include only those nine states with at least some years where both oneyear leases and permanent transfers occurred. A minimum number of years with both types of transactions occurring in a state is required to estimate equation (4) with state fixed effects. ${ }^{5,6}$ The final sample comprises 2,158 transactions in nine states, with one water-supplying sector (agriculture), and two water-buying sectors (agriculture and urban) over the period 1990-2010. The Water Strategist data product ends in 2010, preventing us from extending the dataset further.

On average, there are thirteen permanent transfers and six one-year leases per year in each state (Figure 1). The average annual number of transactions increased for both permanent transfers and leases until the early 2000s, when both dropped significantly, and both have declined slightly since then. On average, there have been more permanent trades than leases, except in 2001 and again in 2008, when the numbers were very close. Figure 1 also shows that the average annual quantity of water permanently transferred by state is much lower and less

\footnotetext{
${ }^{4}$ Until 1995 water transactions were reported in a separate publication associated with the journal Water Intelligence Monthly. Transactions were reported quarterly from 1995-1998 and monthly from 1999-2010. Though prior researchers have made these data available publicly, we reconstruct the entire nine-state, 21-year panel to ensure that the summary data for each transaction (culled from descriptive text in .pdf files) are interpreted consistently.

${ }^{5}$ See the Appendix, Section A1 for an additional discussion regarding omitted data.

${ }^{6}$ Most states have at least one year where they report zero permanent transfers or zero one-year leases.
} 
variable than the annual average quantity leased. Average state water lease and transfer prices have trended upward over time, with significant year-to-year variation (Figure 1).

Summary statistics are reported in Table 1 , which reveals significant heterogeneity across state markets. Over the period 1990-2010, most states averaged fewer than four permanent transfers and fewer than four leases per year. Colorado, in contrast, averaged more than 60 transfers annually, and California averaged more than 12 one-year leases annually.

Transfer and lease prices are converted to 2009 dollars using the consumer price index (CPI) and are expressed in dollars per acre-foot $(\$ / \mathrm{AF}) .^{7}$ As one would expect, the average annual water lease price is much lower than the permanent transfer price for both sectors in all states (Table 1). Price dispersion across states is large, especially in the case of permanent transfers. This is not surprising, as water cannot be transferred or leased across states, similar to prohibitions in fishing quota markets on trades across regions, species, or species-regions. The highest prices for water leased to the urban sector are paid in Texas, but prices for water leased to agriculture are highest in California. Permanent water rights transfers in both sectors are most expensive in Colorado.

To estimate the asset pricing model in equation (4), we aggregate the nine-state water transaction data by state and quarter, so that the dependent variable, $p_{i j q t}$, is the average statequarter permanent transfer price, and $\pi_{i j q t}$ is the average state-quarter one-year lease price. This reduces our sample size to 66 observations in the nine states over the period 1992-2009. Together, six out of nine states account for only 13 observations in the panel, whereas the remaining three states - California, Colorado, and Texas - contribute 13, 17, and 23 observations, respectively. While this small dataset is far from ideal, the Water Strategist is, to

\footnotetext{
${ }^{7}$ An acre-foot, a common unit of volume in U.S. western water trades, is the quantity of water that would flood an acre of land to one foot in depth, about 326,000 gallons.
} 
our knowledge, the only available data that summarize such a large and diverse set of U.S.

western water trades that could be used to test the asset pricing model at this scale.

\subsection{Other data used in the multi-state asset pricing models}

Summary statistics for the remaining variables used in the multi-state asset pricing model are also reported in Table $2 .{ }^{8}$ For the real market interest rate $(\tilde{r})$, we use the 3 -month U.S. Treasury bill rate from the U.S. Federal Reserve (2015) website. Real interest rates are calculated by subtracting the inflation rate (measured by the CPI) from these nominal interest rates.

For the risk premium variable, $\theta$, we use the Irrigation Vulnerability Index (IVI), constructed using the methodology from Liu et al. (2017). The index provides projections of future long-term water stress, which we aggregate by state, dividing the difference between water supply and water use by irrigation water use. In this index, water supply is the sum of surface water (including reservoir storage) and renewable groundwater sources. Water use is the sum of irrigation, domestic, industrial and livestock water use. ${ }^{9}$ Lower values of the IVI indicate higher levels of water stress $(<0.2$ is considered stressed $)$. Additional information about the index is provided in the Appendix, Section A2.

Because the majority of water withdrawals in the region are for irrigation, the growth rate variable $(g)$ in equations (3) and (4) should capture expectations about the future returns to using water as an input to agriculture. We use the growth rate of farmland acres irrigated for this purpose. We know of no projections available for this variable, so we follow Newell, Papps and

\footnotetext{
${ }^{8}$ Table 2 also reports summary statistics for the variables used in estimating the asset pricing model for the Mojave market. These data are discussed further in Section 4.

${ }^{9}$ Water supply, water use and irrigation water use are generated by the University of New Hampshire's Water Balance Model at the grid cell level and at daily time steps and provided here as state-level (and basin-level for the Mojave models in Section 4) annual aggregates, which we then average over the period 2013-2099 to obtain a timeinvariant measure. In cases where water supply is less than water use, groundwater mining is used to fulfill the water use requirement.
} 
Sanchirico (2007), using historical data on farmland acres irrigated at the state level from the USDA Irrigation and Water Management Survey (2019) over the period 1988-2018 to estimate an $\mathrm{AR}(1)$ model expressing growth in value as a function of the natural log of acres irrigated, a time trend, and a constant for each state. ${ }^{10}$ This approach is based on the assumption that the drivers of future growth in irrigated land value will be consistent with past drivers. Given our approach, the estimate of $g$ varies by state, but not over time.

\subsection{Results from the multi-state asset pricing models}

Table 3 reports the results from estimating equation (4) on our multi-state sample. Six models are reported in Table 3: three using data from all nine states and, as a robustness check, three using only observations from the three states with the largest number of transactions in the collapsed panel (California, Colorado and Texas). In these latter models (columns 4-6), the sample size shrinks from 66 to 53. In columns (1) and (4), we include state fixed effects (FE) to control flexibly and comprehensively for unobservable, non-time-varying state water market characteristics. The use of state FEs precludes the identification of coefficients for the risk premium and growth rate variables, neither of which vary over time. Thus, we also estimate a RE model, which assumes that the variation across water rights markets (states) is random and uncorrelated with the explanatory variables in the model. Note that a Hausman test supports the $\mathrm{RE}$ estimator, failing to reject that RE is consistent and efficient. Estimates are very similar across FE and RE models for the coefficients that can be identified in both.

The coefficients on the lease price are positive, and the coefficients on the real interest rate are negative in all six models in Table 3, consistent with the basic principles of asset pricing theory. The magnitude of the lease price coefficient is about one-fifth the size of the analogous

\footnotetext{
${ }^{10}$ This survey was formerly the Farm and Ranch Irrigation Survey. Data are reported every 5 years. The Durbin's $\mathrm{h}$ test statistic of no autocorrelation in AR(1) models was not rejected in all cases except Colorado.
} 
coefficient estimate in the New Zealand fishing quota markets study (Newell, Papps, and Sanchirico 2007). In the New Zealand fishing quota case, the lease price coefficient suggests that a percent change in the lease price will result in a 76 to 86 percent change in the sale price. In our U.S. western water markets case, a percent change in the lease price will result in only a 14 to 17 percent change in the permanent transfer price, suggesting that the connection between lease price and permanent transfer price is weaker in the water markets case. This comparative result is not surprising, given that fishing quota markets in New Zealand may be among the world's most efficient created natural resource asset markets (Grainger and Costello 2011), and may thus represent a "best case" (thus far) for such markets in practice. ${ }^{11}$

The coefficients on the real interest rate, while always negative, are only significant in models without the linear time trend. Not surprisingly, adding the time trend also changes the magnitude of these coefficient estimates.

Recall that our proxy for the risk premium is the long-run IVI. An increase in the index, indicating reduced future risk of water stress and shortage, has a positive impact on the water transfer price in all four models in Table 3 where the coefficient can be identified (the RE models), consistent with the asset pricing model.

The growth variable coefficient in the multi-state model is positive and statistically significant, suggesting that, consistent with asset pricing theory, growth in farmland irrigated acres increases water right transfer prices. Unexpectedly, the three-state sample results show a statistically significant, but negative coefficient associated with the growth variable. This counterintuitive result is not consistent with asset pricing theory. However, robustness check results using a growth variable proxied by crop prices are very similar showing a positive but

\footnotetext{
${ }^{11}$ An anonymous referee recommended that we also compare U.S. western water market performance to that of Australian water markets, using the asset pricing model. We discuss this comparison in the Appendix, section A3.
} 
statistically insignificant coefficient in the nine-state sample, and a negative, statistically significant coefficient in the three-state sample (Appendix Table A3).

One potential threat to identification in Table 3 is that lease prices may be endogenous. That is, while the asset pricing model specifies permanent water transfer prices as a function of one-year lease prices, lease prices could also be determined in part by transfer prices (or farmers may consider both options against the benefit of using water for crops). Thus, we also estimated two-stage least squares (2SLS) models using an instrument for the lease price: the average price specific to year and state excluding local state observations. In all models, an endogeneity test fails to reject the hypothesis that the lease price variable is exogenous. Thus, we interpret the results in Table 3 as the main results and provide 2SLS results in the Appendix, Table A1. ${ }^{12}$

Taken together, the models estimated using the multi-state data suggest that water market activity in the western United States is generally consistent with asset pricing theory. Given the fairly thin markets in this context, as well as the small dataset we are able to construct from the Water Strategist data, these results are encouraging. However, the difference between the efficiency with which information about water's long-run value is transmitted in short-run prices, and that observed in New Zealand fishing quota markets and other natural resource applications, also suggests that these markets have significant efficiency improvement potential.

\section{Mojave water market}

While the Table 3 results are encouraging, the small sample and the heterogeneity of the markets in our multi-state analysis leave the analysis open to criticism that we cannot fully capture this

\footnotetext{
${ }^{12}$ The results of the IV models are qualitatively similar to those in Table 3, with one important exception - the lease price coefficients are positive but statistically insignificant in all reported models. We hesitate to conclude much from this exercise, given that our tests suggest that the lease price is not, in fact, endogenous (suggesting that IV is unnecessary), and the challenges to 2SLS with such a small sample. For example, the test statistics for the IV estimators indicate that the models are only weakly identified, resulting in low first stage F-test statistics.
} 
heterogeneity when pooling state markets together and with the available data. Thus, we also examine the Mojave water rights market, within the Mojave River Basin Area's jurisdiction located in San Bernardino County, California, to see if more active trading in a more homogeneous market comports more closely with the asset pricing model. The Mojave market is a relatively well-defined groundwater market, where monitoring and verification of water production responsibilities are performed by a Watermaster, which also acts as a clearinghouse for trades. We apply the asset pricing model to the Mojave market by re-estimating equation (4) with the Mojave data, instead of the multi-state data used in section 3.

\subsection{Mojave market data and model}

Summary statistics for all the variables used in the asset pricing model estimation for the Mojave market are presented in Table 2. We obtained water transfer data for the Mojave water rights market from the annual Watermaster's water transfer reports posted on the Mojave Water Agency's website (Mojave Water Agency 2016). The dataset consists of groundwater transfers in five subareas (Alto, Baja, Centro, Este, and Oeste). ${ }^{13}$ The data comprise price and quantity information for 3,368 transactions (288 permanent transfers and 3,080 one-year leases) between 1995 and 2018. ${ }^{14}$ Table 4 summarizes the Mojave market data. As expected, and similar to the multi-state case, permanent transfer prices exceed lease prices. As shown in Figure 2, the positive correlation between the transfer and lease prices is stronger in the Mojave market than in the nine-state and three-state samples. That relationship becomes even clearer when we consider only the two most active subareas (Alto and Baja) in the sample. Price dispersion is noticeable across the subareas. Prices for both permanent transfers and leases are highest in the Alto

\footnotetext{
${ }^{13} \mathrm{https} / /$ www.mojavewater.org/files/mbamap_3wm931f0.pdf

${ }^{14}$ Originally the dataset included 4,086 observations. We dropped 718 observations with missing price information and when the reported price was zero.
} 
subarea, followed by Oeste and Centro (Table 4). Price differences could be linked to primary water uses in these areas. In the Mojave Basin Area, water has five different uses: agricultural, municipal, golf course irrigation, industrial, and recreational. The Mojave dataset does not provide information about water uses at the transaction level. However, the Watermaster's Annual Reports (2016) identify major water uses by subarea: Alto - urban, Baja - agricultural, Centro - agricultural and urban, Este - agricultural, Oeste - agricultural and urban. Thus, we can say that water rights prices are highest in the three areas using relatively more urban water, likely reflecting higher-valued uses. The Mojave dataset contains 89 observations (after converting transfer and lease prices to quarterly averages, as we did in the multi-state case), from the five subareas between 1996 and 2018.

There are two differences between the variables in equation (4) for the multi-state asset pricing model described earlier, and those for the Mojave asset pricing model. First, index $j$ represents a subarea in the Mojave model, instead of a state. Second, the constant growth rate $(g)$ in the Mojave model is proxied by the urban and agricultural water consumption growth rate, rather than the growth of acres irrigated. We use urban water consumption data for the Alto, Centro, and Oeste subareas, and agricultural water consumption data for Baja and Este, making $g$ somewhat more asset-specific than we were able to do in the multi-state context (where $g$ varied only by state, because we could not identify the actual location of the transaction at a finer spatial scale). Water consumption data were obtained from the annual Watermaster's reports posted on the Mojave Water Agency website, and they vary by subarea-year, beginning in 2000. Following Newell, Papps and Sanchirico (2007), as we did in the multi-state case, the growth rate variable is estimated using an AR(1) model (where we include the natural log of water consumption, 
year, and a constant) for each subarea. ${ }^{15}$ The estimated value represents the likely future growth in demand for water, assuming the historical drivers of growth will continue into the future.

\subsection{Results for the Mojave market}

Results for the Mojave water rights market case are reported in Table 5. We estimate the same $\mathrm{RE}$ and FE models as we did in the multi-state analysis, starting with the full five-subarea Mojave sample in columns (1) through (3) of Table 5. The results mostly yield the expected coefficient signs: permanent transfer prices are positively correlated with lease prices and the growth rate, and negatively correlated with real interest rates. The magnitude of the lease price coefficient is somewhat higher $(0.18-0.58)$ than in the nine-state sample $(0.14-0.17)$, suggesting a greater influence of lease prices on transfer prices. Unexpectedly, the risk premium coefficient is negative and statistically insignificant, which might be impacted by the relatively smaller area that the Mojave Basin represents, and as a result, less variation. Also, urban water use is dominant in some subareas of the region, which may not be as well-represented by the IVI.

We also estimated the same model on a sample comprising only the two most active subareas in the Mojave region: Alto and Baja. The majority of the quarterly observations in the sample (69 out of 89 area-quarters) are associated with these two areas. The results (shown in columns 4 through 6 of Table 5) imply that the water market consisting of the Alto and Baja subareas of the Mojave exhibits the greatest efficiency among all of the markets we examine, as evident from the large significant coefficient on the lease price (model (5)). In the Alto and Baja subareas of the Mojave market, a one percent change in the one-year lease price will result in a 74 percent change in the permanent water rights price. (The signs for the remaining estimated

\footnotetext{
${ }^{15}$ The Durbin's h test statistic of no autocorrelation was not rejected. The values for water consumption by subarea were not reported until 2000; thus, our proxy is estimated using data from 2000-2018, but the constant growth variable is applied to the entire dataset, 1996-2018.
} 
coefficients are also consistent with asset pricing theory.) As in the multi-state asset pricing model, there is a potential concern about endogenous lease prices, but endogeneity tests suggest that the lease price is exogenous; for completeness, IV results are reported in the Appendix, Table A2, using the same instruments as in the multi-state case (average lease prices by regionyear, excluding local observations). Note that we cannot identify the risk premium (IVI) coefficient in the two-area models, due to insufficient variation.

The results for the Mojave market, a market that is known to have fewer barriers to trade in comparison to the multi-state markets, suggest that there is significant potential for efficiency improvements in other water markets if barriers to trade were addressed.

\section{Conclusions}

We examine the degree to which U.S. western water market prices in nine states act as asset pricing theory would predict. Findings suggest that water market transactions do generally comport with the asset pricing model; for example, permanent water transfer prices are positively correlated with one-year lease prices and negatively correlated with the real interest rate. However, the smaller coefficients associated with lease prices in the water markets in comparison to fishing quota markets suggest significant potential for market efficiency improvements in the water market case.

We find that water market efficiency is highest in one of the most active U.S. water rights markets located in the Mojave Basin Area—markets that are known to have lower barriers to trade. The coefficients on water lease prices are higher in the Mojave markets than in other water markets and, in the case of the two most active areas of the Mojave market, the coefficient on lease prices is almost as high as those in New Zealand fishing quota markets. This difference in results suggests that there is significant potential for efficiency improvements in water rights 
markets in the western U.S., which could lead to higher welfare gains from the reallocation of water.

Taken together, the results provide reason for optimism about water rights markets in the western U.S. Comparing water rights transfers in the U.S. with other natural resource markets allows us to better understand the efficiency potential in these increasingly common markets for created natural resource assets. It is likely that a significant portion of the differences in the relationship between short-term and permanent transfers across different water rights markets, as well as other natural resource markets, can be attributed to the institutions that define and govern these markets. Poor governance across many water markets in the western U.S. is often expressed by the lack of accountability, monitoring, and enforcement. Most surface water and some groundwater rights in the western U.S. are governed by the prior appropriation doctrine, where water rights are allocated based on seniority ("first in time, first in right") leading to greater market frictions. This allocation rule tends to be less significant for short-term transfers, which also tend to be associated with lower transaction costs due to a simpler administrative process. Some regional water markets in the western U.S. are well-functioning. The market in the Mojave River Basin is one of them, which is supported by our findings. Transactions in this market are well recorded and managed, and rights are not allocated based on "first in time, first in right", allowing for faster and less costly transfers.

The ability to quantify the efficiency of water rights transfers as a whole provides an opportunity to measure progress in market development, learn from better-functioning markets, and as a result, advance policies to reduce barriers to water trading. Continuation of the analysis of the price relationship between short- and long-term water transfers is necessary; however, more available data is needed to advance our empirical assessment. Our analysis of the western 
U.S. region was limited with the dataset ending in 2010. Various water management efforts have been progressing since then that are likely to affect water accessibility and management to different water stakeholders in the near future. Examples include: so-called "smart market" development (Young \& Brozović 2016); an attempt to redefine the seniority rule based on the Australian example in Diamond Valley, Nevada (Young 2015, Zeff et al. 2019, Wheeler et al. 2017); the existence of local informal water transfers (Young \& Brozović 2019); and an increase in groundwater protection efforts (e.g., Sustainable Groundwater Management Act in California; Babbitt et al. 2017). Further work that examines the multilayered water rights structures, policies and regulations that support efficient resource reallocation could make a valuable contribution to enhancing water markets' capacity to mitigate anticipated future reductions or increased variation in water supply in the U.S. West and elsewhere. 


\section{References}

Alston, J.M. 1986. “An Analysis of Growth of U.S. Farmland Prices, 1963-82.” American Journal of Agricultural Economics 68(1): 1-9.

Babbitt, C., M. Hall, A. Hayden, A.L. Garcia Briones, R. Young, and N. Brozović, 2017. “Groundwater Trading as a Tool for Implementing California’s Sustainable Groundwater Management Act.” Environmental Defense Fund. Available at https://www.edf.org/sites/default/files/documents/water-markets.pdf

Basta, E. and B.G. Colby, 2010. "Water Market Trends: Transactions, Quantities, and Prices." Appraisal Journal, 78(1), 50-69.

Bjornlund, H., and J. McKay. 2002. “Aspects of Water Markets for Developing Countries: Experiences from Australia, Chile, and the U.S.” Environment and Development Economics 7(4): 769-795.

Brewer, J., R. Glennon, A. Ker, and G. Libecap. 2008. "2006 Presidential Address Water Markets in the West: Prices, Trading and Contractual Forms.” Economic Inquiry 46(2): 91-112.

Brookshire, D.S., B. Colby, M. Ewers, and P.T. Ganderton. 2004. "Market Prices for Water in the Semiarid West of the United States." Water Resources Research 40(9): 1-8.

Brown, T.C., 2006. "Trends in Water Market Activity and Price in the Western United States." Water Resources Research 42.

Bruno, E. M., and K. K. Jessoe. 2019. Water markets and climate change adaptation: micro-level evidence on agricultural water demand. Working Paper, University of California, Berkeley. 
Campbell, J.Y., A.W. Lo, and A.C. MacKinlay. 1997. The Econometrics of Financial Markets. Princeton, NJ: Princeton University Press.

Carey, J., D.L. Sunding, and D. Zilberman. 2002. "Transaction Costs and Trading Behavior in an Immature Water Market." Environment and Development Economics 7(4): 733-750.

Chang, C., and R.C. Griffin. 1992. "Water marketing as a Reallocative Institution in Texas." Water Resources Research 28(3): 879-890.

Cochrane, J.H. 1992. "Explaining the Variance of Price-Dividend Ratios." The Review of Financial Studies 5(2): 243-280.

Colby, B.G., E. Basta, and K. Adams, 2011. "Temporary Water Transactions and Climate Change Adaptation.” In B.G. Colby and G.B. Frisvold, eds. Adaptation and Resilience: The economics of climate, water, and energy challenges in the American Southwest. RFF Press, Washington, DC.

Costello, C., S.D. Gaines, and J. Lynham. 2008. "Can Catch Shares Prevent Fisheries Collapse?” Science 321(5896): 1678-1681.

Diao, X., and T. Roe. 2003. "Can a Water Market Avert the "Double-Whammy" of Trade Reform and Lead to a "Win-Win" Outcome?" Journal of Environmental Economics and Management 45(3): 708-723.

Easter, K.W., M.W. Rosegrant, and A. Dinar, 1999. "Formal and Informal Markets for Water: Institutions, Performance, and Constraints.” The World Bank Research Observer 14(1), 99-116.

Edwards, E.C., and G.D. Libecap. 2015. "Water Institutions and the Law of One Price.” In R. Halvorsen and D.F. Layton eds. Handbook on the Economics of Natural Resources. Edward Elgar Publishing, pp. 442-473. 
Goemans, C., and J. Pritchett, 2014. "Western Water Markets: Effectiveness and Efficiency.” In K.W. Easter and Q. Huang, ed. Water Markets for the 21st Century. What Have We Learned? Global Issues in Water Policy 11.

Grafton, R.Q., G.D. Libecap, E.C. Edwards, R.J. O’Brien, and C. Landry, 2012. “Comparative Assessment of Water Markets: Insights from the Murray-Darling Basin of Australia and the Western USA.” Water Policy, 14(2), 175-93.

Grafton, R.Q., J. Horne, S. Wheeler, 2016. “On the marketisation of water: Evidence from the Murray-Darling Basin, Australia.” Water Resources Management 30(3), pp. 913-926.

Grainger, C.A., and C. Costello. 2011. "The Value of Secure Property Rights: Evidence from Global Fisheries." The National Bureau of Economic Research. Working Paper No. 17019.

- 2014. "Capitalizing Property Rights Insecurity in Natural Resource Assets.” Journal of Environmental Economics and Management 67(2): 224-240.

Hagerty, N. 2019. "Liquid Constrained: Estimating the Potential Gains from Water Markets." University of California, Berkeley. Working Paper.

Hansen, K., R. Howitt, and J. Williams, 2013. "Water Trades in the Western United States: Risk, Speculation, and Property Rights.” In J. Maetsu, ed. Water Trading and Global Water Scarcity: International Perspectives.

Hansen, K., R. Howitt, and J. Williams, 2014. “An Econometric Test of Water Market Structure in the Western United States.” Natural Resources Journal 55, 127-152.

Hartman, L. M., and D. Seastone. 1970. "Water Transfers: Economic Efficiency and Alternative Institutions." Baltimore, MD: Johns Hopkins University Press. 
Hearne, R., and G. Donoso. 2014. “Water Markets in Chile: Are They Meeting Needs?” In K.W. Easter and Q. Huang eds. Water Markets for the $21^{\text {st }}$ Century. Global Issues in Water Policy: Springer, Dordrecht, pp. 103-126.

Hearne, R.R., and K.W. Easter. 1997. "The Economic and Financial Gains from Water Markets in Chile." Agricultural Economics 15(3): 187-199.

Howe, C.W. and C. Goemans, 2003. "Water Transfers and Their Impacts: Lessons from Three Colorado Water Markets.” Journal of the American Water Resources Association, 39(5), 1055-1065.

Howitt, R.E. and K.M. Hansen, 2005. “The Evolving Western Water Markets. Choices 20(1).

Huffaker R. 2005. "Finding a Modern Role for the Prior Appropriation Doctrine in the American West.” In C. Gopalakrishnan, C. Tortajada, and A.K. Biswas eds. Water Institutions: Policies, Performance and Prospects. Springer, pp. 187-200.

Keohane, N.O. 2007. "Cost Savings from Allowance Trading in the 1990 Clean Air Act: Estimates from a Choice-Based Model.” In: J. Freeman, and C.D. Kolstad, eds. Moving to Markets in Environmental Regulation. New York: Oxford University Press, pp. 194229.

Libecap, G.D., 2010. "Water Rights and Markets in the U.S. Semi-Arid West: Efficiency and Equity Issues.” In: Proceedings of the Conference on The Evolution of Property Rights Related to Land and Natural Resources, Lincoln House, Cambridge, Massachusetts, September 20-21, 2010.

Liu J., Hertel T., Lammers R., Prusevich A., Baldos U., Grogan D.S., Frolking, S. Achieving sustainable irrigation water withdrawals: Global impacts on food security and land use. Environ. Res. Lett. 12 (2017) 104009, doi:10.1088/1748-9326/aa88db. 
Loch, A., S. Wheeler, C. Settre, 2018. "Private transaction costs of water trade in the MurrayDarling Basin. Ecological Economics.” 146, pp. 560-573.

Mojave Water Agency. Water Transfer Reports. https://www.mojavewater.org /water_transfer_reports.html (accessed 15 August 2016).

- Watermaster Annual Reports. https://www.mojavewater.org /annual_report.html (accessed 15 August 2016).

National Research Council. 2001. Compensating for Wetland Losses Under the Clean Water Act. Washington, DC: National Academies Press.

Newell, R.G., K.L. Papps, and J.N. Sanchirico. 2007. “Asset Pricing in Created Markets.” American Journal of Agricultural Economics 89(2): 259-272.

Newell, R.G., J.N. Sanchirico, and S. Kerr. 2005. "Fishing Quota Markets.” Journal of Environmental Economics and Management 49(3): 437-462.

Olmstead, S.M. 2010. “The Economics of Managing Scarce Water Resources.” Review of Environmental Economics and Policy 4(2): 179-198.

Olmstead, S.M., K.A., Fisher-Vanden, and R. Rimsaite, 2016. "Climate Change and Water Resources: Some Adaptation Tools and Their Limits." Journal of Water Resource Planning and Management, 142(6).

Parkhurst, G.M., and J.F. Shogren. 2003. "Evaluating Incentive Mechanisms for Conserving Habitat.” Natural Resources Journal 43(4): 1093-1149.

Pujol, J., M. Raggi, and D. Viaggi. 2006. “The Potential Impact of Markets for Irrigation Water in Italy and Spain: A Comparison of Two Study Areas.” Australian Journal of Agricultural and Resource Economics 50(3): 361-380. 
Rey, D., A. Garrido, and J. Calatrava. 2014. "Water Markets in Spain: Meeting Twenty-First Century Challenges with Twentieth Century Regulations.” In K.W. Easter and Q. Huang eds. Water Markets for the $21^{\text {st }}$ Century. Global Issues in Water Policy: Springer, Dordrecht, pp. 127-147.

Rosegrant, M.W., C. Ringler, and T. Zhu, 2014. "Water Markets and Adaptive Response to Climate Change.” In K.W. Easter and Q. Huang eds. Water Markets for the $21^{\text {st }}$ Century. Global Issues in Water Policy: Springer, Dordrecht, pp. 35-55.

Saliba, B., and D.B. Bush. 1987. Water Markets in Theory and Practice. Boulder, CO: Westview Press.

Smith, R.T., ed., 2002-2010. Transactions. Water Strategist. Stratecon, Claremont, CA.

Smith, R.T., and R.J. Vaughan, eds., 1990-1994. Transactions. Water Intelligence Monthly. Stratecon, Claremont, CA.

- 1995-2001. Transactions. Water Strategist. Stratecon, Claremont, CA.

Scott A., and G. Coustalin. 1995. "The Evolution of Water Rights.” Natural Resources Journal 35: $821-980$.

Schmalensee, R., and R.N. Stavins. 2017. "The Design of Environmental Markets: What Have We Learned from Experience with Cap and Trade?" Oxford Review of Economic Policy 33(4): 572-588.

Teitenberg, T.H., 1990. “Economic Instruments for Environmental Regulation.” Oxford Review of Economic Policy 6(1): 17-33

Tisdell, J. 2014. “The Evolution of Water Legislation in Australia.” In K.W. Easter and Q. Huang (eds.), Water Markets for the $21^{\text {st }}$ Century. Global Issues in Water Policy: Springer, Dordrecht, pp. 163-178. 
USDA Irrigation and Water Management Survey: https://www.nass.usda.gov/Surveys /Guide_to_NASS_Surveys/Farm_and_Ranch_Irrigation/(accessed December 10 2019). U.S. Federal Reserve. Selected Interest Rates: http://www.federalreserve.gov/releases /h15/data.htm (accessed November 12 2015).

Vaux, H. J., and Richard E. Howitt. 1984. "Managing Water Scarcity: An Evaluation of Interregional Transfers." Water Resources Research. 20:785-792.

Wilson, N., and D.A. Sumner. 2004. "Explaining Variations in the Price of Dairy Quota: Flow Returns, Liquidity, Quota Characteristics, and Policy Risk.” Journal of Agricultural and Resource Economics 29(1): 1-16.

Wheeler, S., H. Bjornlund, and A. Loch. 2014. "Water Trading in Australia: Tracing Its' Development and Impact Over the Past Three Decades.” In K.W. Easter and Q. Huang (Ed.), Water Markets for the $21^{\text {st }}$ Century. Global Issues in Water Policy: Springer, Dordecht, pp. 179-202.

Wheeler, S., A. Loch, L. Crase, M. Young, R. Grafton, 2017. "Developing a water market readiness assessment framework." Journal of Hydrology 552, pp. 807-820.

Yoskowitz, D.W. 1999. "Spot Market for Water Along the Texas Rio Grande: Opportunities for Water Management." Natural Resources Journal 39(2): 345-355.

Young, M. 2015. “Unbundling Water Rights: A Blueprint for Development of Robust Water Allocation Systems in the Western United States.” NI R 15-01. Durham, NC: Duke University. http://nicholasinstitute.duke.edu/publications.

Young, R., and N. Brozović, 2016."Innovations in Groundwater Management: Smart Markets for Transferable Groundwater Transaction Rights.” Technology \& Innovation, 17(4), 2019-226. 
Young, R., and N. Brozović,, 2019. "Agricultural Water Transfers in the Western United States." Daugherty Water for Food Global Institute and Mammoth Trading. Available at https://waterforfood.nebraska.edu/-/media/projects/dwfi/documents/resources/2019agricultural-water-transfers-report.pdf?la=en

Zeff, H., D. Kaczan, G.W.,Characklis, M. Jeuland, B. Murray, \& K. Locklier, 2019. “Potential Implications of Groundwater Trading and Reformed Water Rights in Diamond Valley, Nevada." Journal of Water Resources Planning and Management, 145(6), 05019009.

Zuo, A., S. Wheeler, W. Adamowicz, P. Boxall, D. Hatton-MacDonald, 2015. "Measuring price elasticities of demand and supply of water entitlements based on stated and revealed preference data." American Journal of Agricultural Economics 98(1), pp. 314-332. 
Table 1. Annual Average Transactions, Quantities, and Prices by State and for the Full Nine-State Sample, 1990-2010

\begin{tabular}{|c|c|c|c|c|c|c|c|c|c|c|c|c|c|c|}
\hline \multirow{2}{*}{ State } & \multirow{2}{*}{$\begin{array}{l}\text { Number } \\
\text { of leases }\end{array}$} & \multirow{2}{*}{$\begin{array}{l}\text { Number of } \\
\text { transfers }\end{array}$} & \multicolumn{3}{|c|}{ Qty. leased (AF) } & \multicolumn{3}{|c|}{ Qty. transferred (AF) } & \multicolumn{3}{|c|}{ Lease price $(\$ / A F)$} & \multicolumn{3}{|c|}{ Transfer price $(\$ / A F)$} \\
\hline & & & to urb & to ag & total & to urb & to ag & total & urb & ag & total & urb & $\mathrm{ag}$ & total \\
\hline $\mathrm{AZ}$ & 2.3 & 2.6 & 259253 & 237671 & 222668 & 3585 & 825 & 3380 & 103 & 59 & 68 & 1347 & 835 & 1182 \\
\hline $\mathrm{CA}$ & 12.1 & 2.2 & 14464 & 8523 & 9371 & 12206 & 9978 & 11839 & 130 & 68 & 91 & 2129 & 953 & 1998 \\
\hline $\mathrm{CO}$ & 3.4 & 64.0 & 7903 & 5304 & 8042 & 148 & 31 & 115 & 100 & 29 & 78 & 10456 & 7184 & 10142 \\
\hline ID & 3.4 & 1.7 & 11805 & 15557 & 15583 & 1140 & 1700 & 1604 & 14 & 11 & 12 & 645 & 1095 & 988 \\
\hline NM & 1.0 & 2.2 & $\mathrm{n} / \mathrm{a}$ & 22455 & 22455 & 164 & 774 & 232 & $\mathrm{n} / \mathrm{a}$ & 46 & 46 & 4177 & 2701 & 4013 \\
\hline NV & 1.0 & 2.3 & 7700 & 448 & 5283 & 625 & $\mathrm{n} / \mathrm{a}$ & 625 & 45 & 43 & 45 & 9243 & $\mathrm{n} / \mathrm{a}$ & 9243 \\
\hline TX & 9.1 & 3.7 & 1885 & 7413 & 3852 & 10025 & 7217 & 9196 & 224 & 31 & 162 & 1655 & 1288 & 1618 \\
\hline UT & 1.4 & 1.8 & 3037 & 9944 & 9312 & 677 & 94 & 538 & 181 & 7 & 30 & 1693 & 1410 & 1566 \\
\hline WA & 1.4 & 1.4 & 1320 & 5352 & 5005 & 15209 & 1370 & 15336 & 80 & 34 & 39 & 819 & 266 & 842 \\
\hline Total & 26.7 & 76.0 & 10809 & 19505 & 16951 & 884 & 1101 & 849 & 183 & 49 & 109 & 9342 & 5780 & 8944 \\
\hline
\end{tabular}

Note: All statistics are yearly averages weighted by number of transactions that occurred in each year during the period 1990-2010. Most states do not have observations for every year of this period. Number of leases and number of transfers indicate an annual average number of 1-year leases and permanent transfers for each state, conditional on a lease/transfer (e.g., AZ had 23 permanent transfers, which occurred during 9 years during 1990-2010; hence, the annual average number of transfers is 2.6). Qty. leased and transferred is an annual average transferred to urban, to agricultural, and to both (total) uses. Lease and transfer prices indicate annual average price per acre-foot paid for water to be used in urban, agricultural, and both (total) sectors. Total average (bottom row) is the mean of 21 yearly averages over the period 1990-2010 without state weights (e.g., total of 1,597 transfers across the 9 states during 21 years is 76 transfers/year); the total average in the bottom row does not equal the sum of state averages due to the unbalanced panel (e.g., in Arizona, permanent transfers occurred in 9 years during the 1990-2010 period, but only 8 of those years showed transactions to urban uses, and only 3 of those years showed transactions to agricultural uses). 
Table 2. Summary Statistics for the Asset pricing Models

\begin{tabular}{|c|c|c|c|c|c|c|c|c|}
\hline & \multicolumn{4}{|c|}{ Nine-state model } & \multicolumn{4}{|c|}{ Mojave market model } \\
\hline & Mean & Std. Dev. & Min & Max & Mean & Std. Dev. & Min & Max \\
\hline Transfer price (\$/AF) & 4504.23 & 6451.63 & 76.44 & 28298.85 & 2108.13 & 1794.43 & 58.51 & 5546.25 \\
\hline Lease price $(\$ / A F)$ & 95.25 & 108.57 & 1.47 & 559.48 & 122.63 & 123.01 & 1.00 & 422.58 \\
\hline \multicolumn{9}{|l|}{ Growth rate: } \\
\hline Farm acres irrigated & 0.10 & 0.35 & -0.76 & 0.75 & & & & \\
\hline Water consumption & & & & & 0.50 & 0.26 & 0.13 & 0.95 \\
\hline \multicolumn{9}{|l|}{ Risk premium: } \\
\hline Real interest rate & 0.01 & 0.02 & -0.02 & 0.03 & -0.00 & 0.02 & -0.03 & 0.03 \\
\hline Areas $(\mathrm{J})$ & \multicolumn{4}{|c|}{9 states: AZ, CA, CO, ID, NM, NV, TX, UT, WA } & \multicolumn{4}{|c|}{5 Subareas: Alto, Baja, Centro, Este, Oeste } \\
\hline Quarters (Q) & \multicolumn{4}{|l|}{4} & \multicolumn{4}{|l|}{4} \\
\hline Years $(\mathrm{T})$ & \multicolumn{4}{|c|}{$18(1992-2009)$} & \multicolumn{4}{|c|}{$24(1995-2018)$} \\
\hline Observations (N) & \multicolumn{4}{|l|}{66} & \multicolumn{4}{|l|}{89} \\
\hline
\end{tabular}


Table 3. Asset Pricing Model Results for the Nine-State Sample (Dependent Variable: Log Transfer Price)

\begin{tabular}{|c|c|c|c|c|c|c|}
\hline & $\begin{array}{c}(1) \\
\text { (9 states) }\end{array}$ & $\begin{array}{c}(2) \\
\text { (9 states) }\end{array}$ & $\begin{array}{c}(3) \\
\text { (9 states) }\end{array}$ & $\begin{array}{c}(4) \\
\text { (3 states) }\end{array}$ & $\begin{array}{c}(5) \\
(3 \text { states })\end{array}$ & $\begin{array}{c}(6) \\
\text { (3 states) }\end{array}$ \\
\hline$\overline{\text { Log lease price }}$ & $\begin{array}{l}0.154 * \\
(0.070)\end{array}$ & $\begin{array}{c}0.172 * * \\
(0.076)\end{array}$ & $\begin{array}{c}0.171 * * * \\
(0.064)\end{array}$ & $\begin{array}{c}0.146 \\
(0.071)\end{array}$ & $\begin{array}{c}0.146^{* *} \\
(0.072)\end{array}$ & $\begin{array}{c}0.153 * * \\
(0.063)\end{array}$ \\
\hline Growth rate: Acres & 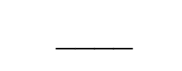 & $1.154 *$ & $1.039 *$ & & $-1.650 * * *$ & $-2.395 * * *$ \\
\hline irrigated & & $(0.631)$ & $(0.617)$ & & $(0.061)$ & $(0.141)$ \\
\hline Risk premium: Irrigation & 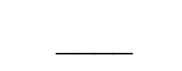 & $0.046 * * *$ & $0.052^{* * *}$ & 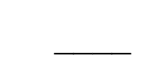 & $1.476^{* * *}$ & $1.349 * * *$ \\
\hline vulnerability index & & $(0.013)$ & $(0.012)$ & & $(0.069)$ & $(0.092)$ \\
\hline Real interest rate & $\begin{array}{c}-20.061 * * \\
(7.320)\end{array}$ & $\begin{array}{c}-20.164 * * * \\
(7.514)\end{array}$ & $\begin{array}{l}-9.403 \\
(6.571)\end{array}$ & $\begin{array}{l}-22.767 \\
(8.306)\end{array}$ & $\begin{array}{c}-22.767 * * * \\
(8.477)\end{array}$ & $\begin{array}{l}-11.437 \\
(7.851)\end{array}$ \\
\hline Time trend & 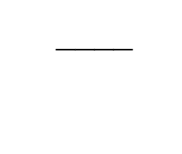 & 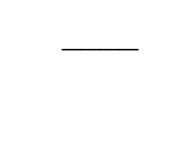 & $\begin{array}{c}0.070 * * * \\
(0.013)\end{array}$ & 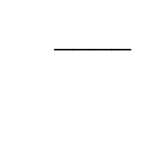 & 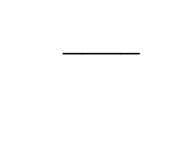 & $\begin{array}{c}0.068 * * * \\
(0.017)\end{array}$ \\
\hline State controls & $\mathrm{FE}$ & $\mathrm{RE}$ & $\mathrm{RE}$ & $\mathrm{FE}$ & $\mathrm{RE}$ & $\mathrm{RE}$ \\
\hline $\mathrm{N}$ (obs) & 66 & 66 & 66 & 53 & 53 & 53 \\
\hline $\mathrm{R}^{2}$ & 0.212 & 0.053 & 0.106 & 0.269 & 0.724 & 0.788 \\
\hline
\end{tabular}

Note: $* * *$ Significance at $1 \%, * *$ Significance at $5 \%, *$ Significance at $10 \%$; values in parentheses are robust standard errors clustered by state. All models include a constant. Robustness checks using a different proxy (major irrigated crop prices instead of acres-irrigated) for the growth rate variable are reported in Appendix, Table A3. 
Table 4. Annual Average Transfers, Quantities and Prices by Subarea and for the Total Mojave Sample

\begin{tabular}{lllllll}
\hline Subarea & $\begin{array}{l}\text { Number } \\
\text { of leases }\end{array}$ & $\begin{array}{l}\text { Number of } \\
\text { transfers }\end{array}$ & $\begin{array}{l}\text { Qty. leased } \\
(\mathrm{AF})\end{array}$ & $\begin{array}{l}\text { Qty. transferred } \\
(\mathrm{AF})\end{array}$ & $\begin{array}{l}\text { Lease price } \\
(\$ / \mathrm{AF})\end{array}$ & $\begin{array}{l}\text { Transfer price } \\
(\$ / \mathrm{AF})\end{array}$ \\
\hline Alto & 86.1 & 7.3 & 224 & 199 & 174 & 2908 \\
Baja & 23.8 & 3.3 & 119 & 115 & 25 & 349 \\
Centro & 6.4 & 3.7 & 226 & 331 & 43 & 1263 \\
Este & 9.0 & 1.7 & 47 & 199 & 36 & 494 \\
Oeste & 3.6 & 1.2 & 370 & 704 & 67 & 2486 \\
\hline Total & 128 & 12.0 & 197 & 219 & 137 & 1710 \\
\hline
\end{tabular}

Note: All statistics are yearly averages. The total 5-subarea market statistics are yearly averages without subarea weights. 
Table 5. Asset pricing model results for the Mojave sample (Dependent Variable: Log Transfer Price)

\begin{tabular}{|c|c|c|c|c|c|c|}
\hline & $\begin{array}{c}(1) \\
\text { (5 areas) }\end{array}$ & $\begin{array}{c}(2) \\
(5 \text { areas })\end{array}$ & $\begin{array}{c}(3) \\
(5 \text { areas })\end{array}$ & $\begin{array}{c}(4) \\
(2 \text { areas })\end{array}$ & $\begin{array}{c}(5) \\
(2 \text { areas })\end{array}$ & $\begin{array}{c}(6) \\
(2 \text { areas })\end{array}$ \\
\hline Log lease price & $\begin{array}{l}0.413 \\
(0.285)\end{array}$ & $\begin{array}{l}0.584 * * \\
(0.239)\end{array}$ & $\begin{array}{c}0.179 \\
(0.216)\end{array}$ & $\begin{array}{l}0.736^{*} \\
(0.115)\end{array}$ & $\begin{array}{c}0.736 * * * \\
(0.116)\end{array}$ & $\begin{array}{c}0.401 \\
(0.313)\end{array}$ \\
\hline $\begin{array}{l}\text { Growth rate: Water } \\
\text { consumption }\end{array}$ & 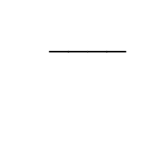 & $\begin{array}{l}1.385 * * * \\
(0.359)\end{array}$ & $\begin{array}{l}1.750 * * * \\
(0.223)\end{array}$ & 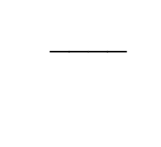 & $\begin{array}{l}2.116^{* * *} \\
(0.589)\end{array}$ & $\begin{array}{c}2.674 * * * \\
(0.736)\end{array}$ \\
\hline $\begin{array}{l}\text { Risk premium: Irrigation } \\
\text { vulnerability index }\end{array}$ & 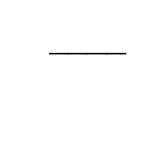 & $\begin{array}{l}-0.026 \\
(0.024)\end{array}$ & $\begin{array}{l}-0.024 \\
(0.015)\end{array}$ & & 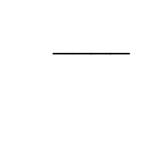 & - \\
\hline Real interest rate & $\begin{array}{l}-14.096 \\
(8.480)\end{array}$ & $\begin{array}{l}-9.859 \\
(8.504)\end{array}$ & $\begin{array}{l}-2.441 \\
(3.725)\end{array}$ & $\begin{array}{l}-3.724 \\
(7.131)\end{array}$ & $\begin{array}{l}-3.724 \\
(7.185)\end{array}$ & $\begin{array}{l}-2.290 \\
(3.436)\end{array}$ \\
\hline Time trend & 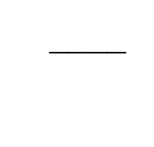 & 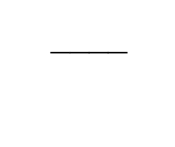 & $\begin{array}{l}0.043 * * \\
(0.018)\end{array}$ & 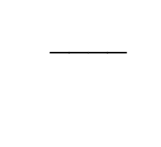 & 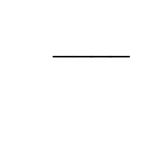 & $\begin{array}{c}0.025 \\
(0.018)\end{array}$ \\
\hline Subarea controls & $\mathrm{FE}$ & $\mathrm{RE}$ & $\mathrm{RE}$ & FE & $\mathrm{RE}$ & $\mathrm{RE}$ \\
\hline $\mathrm{N}$ (obs) & 89 & 89 & 89 & 69 & 69 & 69 \\
\hline $\mathrm{R}^{2}$ & 0.480 & 0.717 & 0.799 & 0.756 & 0.903 & 0.914 \\
\hline
\end{tabular}

Note: *** Significance at $1 \%$, ** Significance at 5\%, ${ }^{*}$ Significance at $10 \%$; values in parentheses are robust standard errors, clustered by state. All models include a constant. The proxy for the growth rate variable is historical urban water consumption in the case of Alto, Centro and Oeste and agricultural water consumption in the case of Baja and Este. 


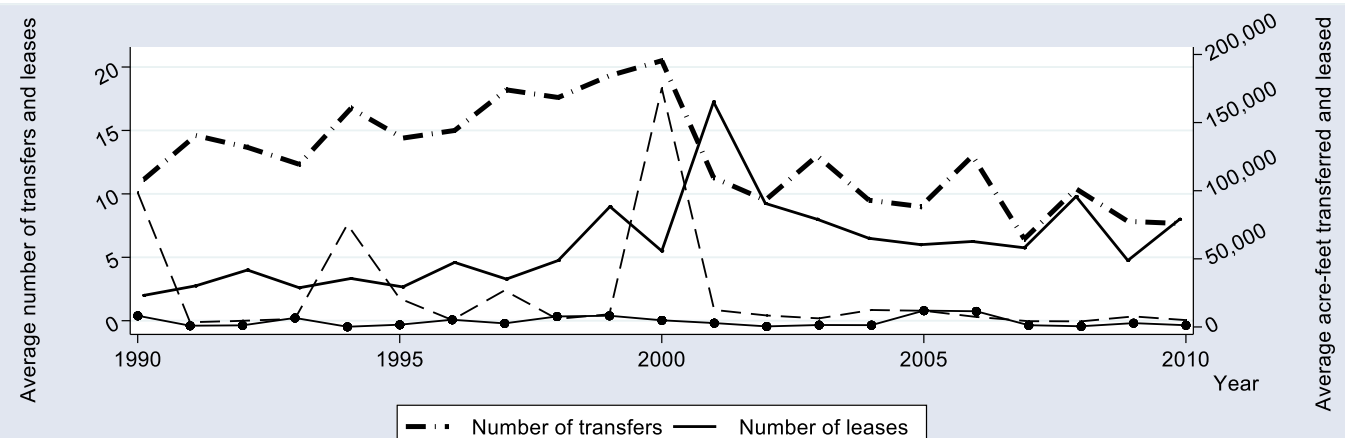

$\begin{array}{lll}-\cdots & \text { Number of transfers }- & \text { Number of leases } \\ \rightarrow- & \text { Quantity transferred }-- & \text { Quantity leased }\end{array}$

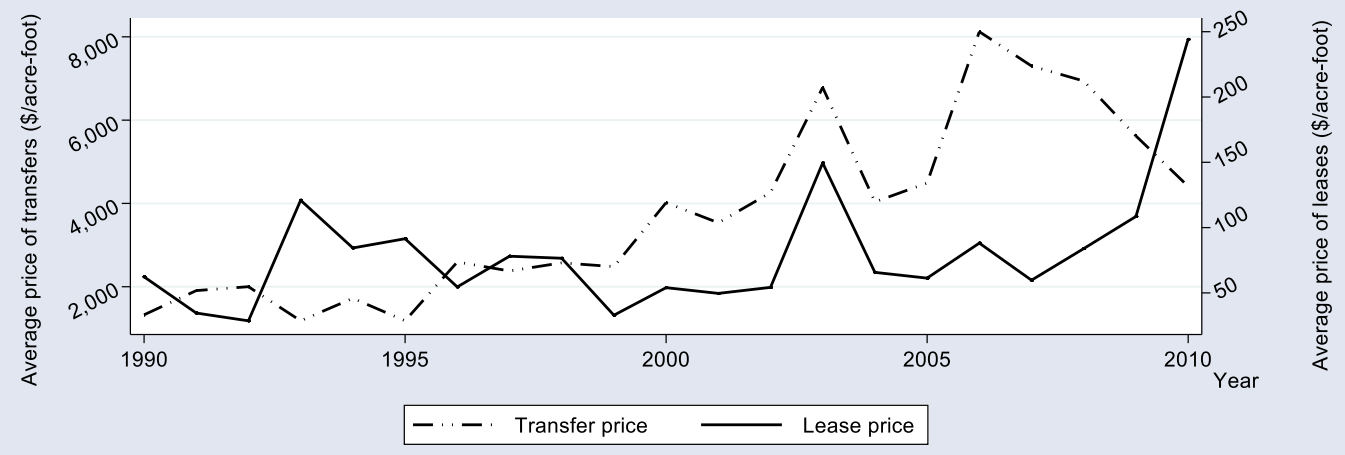

Figure 1. Average number of transactions and quantity traded (top) and average prices of transactions (bottom) in the nine-state water market sample 

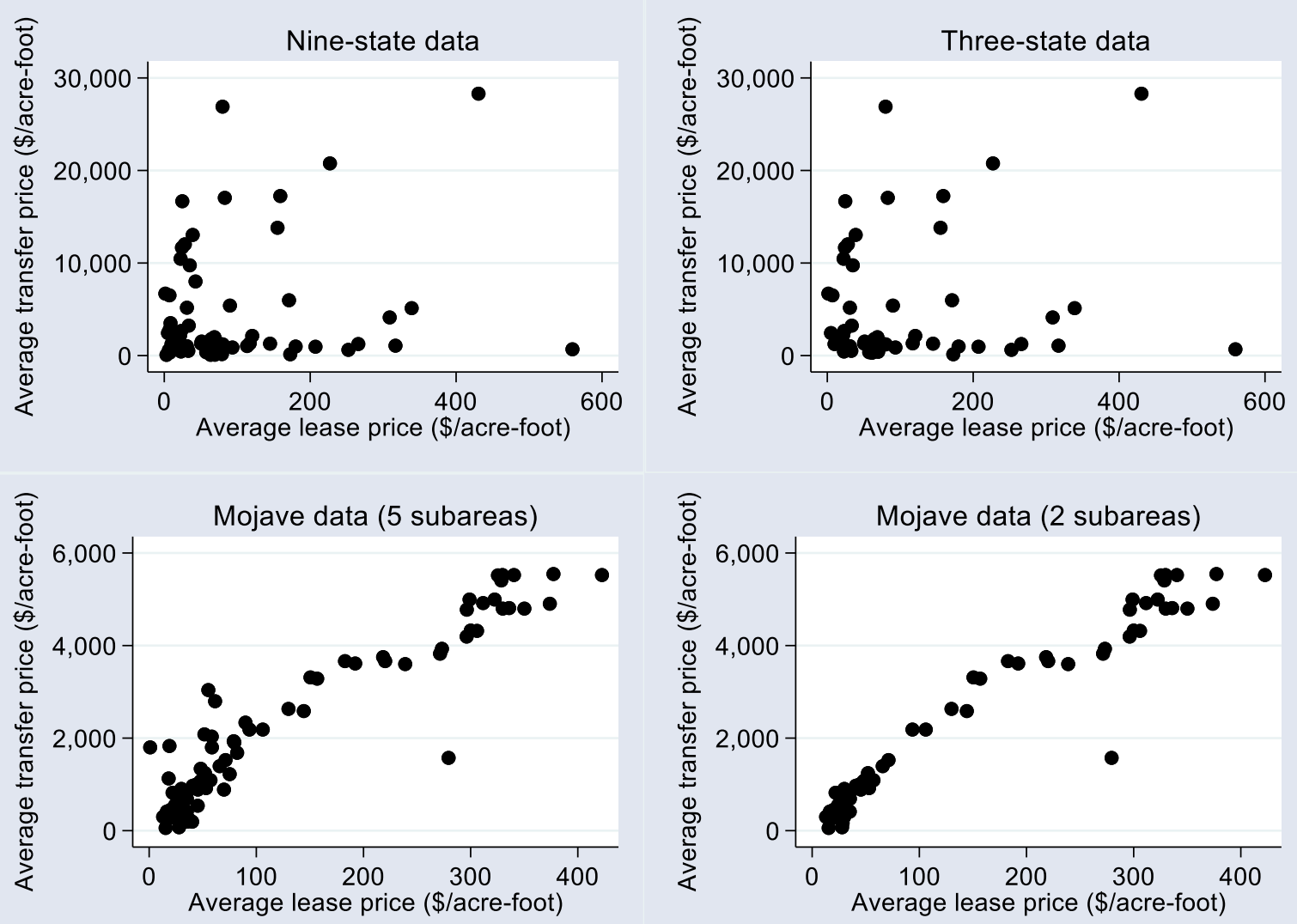

Figure 2. Average (quarterly) lease and transfer prices in the multi-state data and the Mojave data 


\section{A. APPENDIX}

\section{A1. Additional water transfer dataset description}

The full nine-state water transactions sample from the Water Strategist includes 5,099 observations. The original data included 12 states (5,467 transactions); however, two of those states (Oregon and Wyoming) had no recorded permanent transfers and one state (Montana) had only one recorded permanent transfer. Both permanent transfers and one-year leases within a state-year are required to empirically estimate the asset pricing model; therefore, these three states were dropped from our sample.

Buyers and sellers are grouped into three main categories: agricultural, urban, and environmental sectors. Water rights transactions generally happen in one of three forms: permanent transfers, one-year leases and multi-year leases. Long-term leases vary greatly in length across observations ( 2 to 100 years) and represent the smallest number of transactions in this dataset. In this study, we focus on two types of market transactions: water rights permanent transfers and one-year leases. We omit observations associated with recycled effluent water, storage rights, and multi-year leases. ${ }^{16}$ In order to provide a better understanding of quantities and prices in the market, we also omit observations with missing prices, prices lower than $\$ 1 /$ acre-foot, and unidentified buyers. ${ }^{17}$

Water market issues related to environmental flows are unique, complex, and beyond the scope of this paper; we eliminate 529 transactions involving that sector. The agricultural sector is

\footnotetext{
${ }^{16} 154$ (out of 5,099) observations are associated with reclaimed effluent water; 47 (out of 5,099) trades involve storage rights; 407 (out of 5,099) observations are leasing contracts for longer than 1-year period. (The groups of omitted observations are not mutually exclusive.)

${ }^{17}$ The actual price of the transaction was missing in 1,423 (out of 5,099) transactions, mostly for the following reasons: 1) the price was not provided;2) the price was provided for a transaction that included both land and water; or 3) water rights were dedicated or exchanged for in-kind services. We dropped 32 transactions with a price lower than $\$ 1 /$ af. We also dropped two outliers with one-year lease prices higher than $\$ 5,400 /$ af, (the average one-year lease price is $\$ 109 / \mathrm{af})$. We also dropped 419 transactions not reporting the sector of the buyer.
} 
the largest water supplier in the western states; thus, we keep only those transactions that were associated with water coming from agricultural irrigators, eliminating the 702/5,099 water transactions where the urban sector was the seller or lessor.

\section{A2. Irrigation Vulnerability Index}

The Irrigation Vulnerability Index (IVI) is constructed as in Liu et al. (2017), using their data to construct our proxy for the risk premium $(\theta)$ in the asset pricing models. In this approach, irrigation vulnerability is defined as:

(water supply-water use) / irrigation water use where water supply is the sum of surface water (including reservoir storage) and renewable groundwater sources. Water use is the sum of irrigation, domestic, industrial, and livestock water use. Lower values of the index indicate higher levels of water stress. An irrigation vulnerability $<0.2$ is considered stressed. Irrigation vulnerability can have negative values, which occur where unsustainable water supplies are used to fulfill the water use category.

Water supply, water use, and irrigation water use are simulated by the University of New Hampshire's Water Balance Model (WBM) at the grid cell level and at a daily time step and provided here as state-level (and basin-level for the Mojave), annual aggregates. Where water supply is less than water use, unsustainable groundwater is used to fulfill the water use requirement.

WBM simulations for 2013 - 2099 are driven by the GISS-E2-R RCP 8.5 climate scenario, bias-corrected using the delta change method. The obtained annual IVI values were averaged over this long-run period for each state to show the mean projection for long-term water stress. Results suggest that Arizona is projected to be most stressed in irrigation water availability followed by California, Texas, and Colorado (Table A4). 
Note the exceptionally high value of the index for the state of Nevada. While this is an unusual value, Nevada contributes a small number of transactions to our multi-state sample, and the main results are robust to dropping Nevada (along with all other states except California, Colorado and Texas), as noted in the discussion of Table 3 in the main paper. Thus, this value does not appear to substantially influence our results.

\section{A.2.1. WBM methods and data for simulating water use and water supply}

Note: these methods have been published before, and the relevant citations are: Wisser et al. (2010), Grogan (2016), and Liu et al. (2017).

\section{Irrigation water use}

\section{Input data}

Inputs to WBM for simulation irrigation water use are: crops maps, soil properties, crop parameters, daily mean temperature, and daily precipitation. Crop maps (i.e., the location, growing area, and growing season) are from the MIRCA2000 data base (Portmann et al 2000). Soil properties - namely, field capacity and soil available water capacity - are from the Harmonized World Soil Database v1.1 (FAO/IIASA/ISRIC/ISSCAS/JRC, 2009). Crop parameters $k_{c}, C D F_{c}$, and $R D_{c}$ are from Siebert and Döll (2010). We use the GISS-E2-R global circulation model (Schmidt et al., 2014) representative concentration pathway (RCP) 8.5 to provide temperature and precipitation inputs.

\section{Method}

In WBM, crops extract water from the soil moisture each day of the crop's growing season. Given sufficient water in the soil moisture pool, the amount of water used by each crop is the crop potential evapotranspiration, PETc [mm]: 
$P E T_{c}=k_{c} \cdot P E T_{0}$

where $P E T_{0}[\mathrm{~mm}]$ is a reference evapotranspiration, and $k_{c}[-]$ is a crop-specific, time-varying scalar. This method follows the FAO-recommended crop-modeling methodology outlined in Allen et al (1998). Here, we use the Penman-Monteith method for estimating PET $_{0}$ (Allen et al, 1998).

If soil moisture levels fall below a crop-specific threshold, $S M T_{c}[\mathrm{~mm}]$, then irrigation water is called for. Soil moisture threshold $S M T_{c}$ for $\operatorname{crop} c$ is:

$$
S M T_{c}=C D F_{c} \cdot R D_{c} \cdot A W_{c a p}
$$

where $C D F_{c}[-]$ is a crop depletion factor, $R D_{c}[\mathrm{~mm}]$ is the crop's root depth, and $A W c a p[-]$ is the soil's available water capacity.

When soil moisture is below $S M T_{c}$, then the time step's net irrigation water demand, $I_{n e t, t}$, is the difference between the current soil moisture and field capacity:

$I_{n e t, t}=\left\{\begin{array}{l}F c a p-S M_{t} \text { if } S M_{t} \leq S M T_{c} \\ 0 \text { if } S M_{T}>S M T_{c}\end{array}\right.$

where Fcap $[\mathrm{mm}]$ is the soil's field capacity, and $S M_{t}[\mathrm{~mm}]$ is the soil moisture at time $t$. Annual net irrigation water use is the sum of all daily net irrigation water uses through the year. We assume no shortage of water for irrigation; when water supply is insufficient to meet the crop's irrigation water requirement, then additional water is added to the soil moisture from an unlimited "unsustainable" water source.

\section{Domestic and industrial water use}




\section{Input data}

Data inputs for domestic and industrial water use are: domestic per capita water use, industrial per capita water use, and population density. Time series of domestic per capita water use, $D W p p$ and industrial per capita water use, IWpp, are from Liu et al (2017). Annual population density projections are from the IIASA decadal projections (IIASA, 2007) under the B2 scenario.

\section{Method}

In WBM, the domestic and industrial sectors use water each day. Domestic water use, $D w[\mathrm{~mm}]$, is:

$D w=A \cdot D W p p \cdot D_{p o p}$,

and industrial water use, $I w[\mathrm{~mm}]$ is:

$I w=A \cdot I W p p \cdot D_{p o p}$,

where

$A\left[\mathrm{~km}^{2}\right]$ is the area of the grid cell

$D W p p[\mathrm{~mm} / \mathrm{d}]$ is the domestic water use per capita

$I W p p[\mathrm{~mm} / \mathrm{d}]$ is the industrial water use per capita

$D_{\text {pop }}\left[\right.$ persons $\left.\mathrm{km}^{-2}\right]$ is the population density.

\section{Livestock water use}

\section{Input data}

Input data for livestock water use are: average daily temperature, livestock density for each livestock category, service water per head, and two growth parameters. All livestock data and methods are from FAO (2006) and FAO employee Dominik Wisser (personal communication); the same temperature inputs are used here as in the irrigation water use section. 


\section{Method}

Daily livestock water, $L_{w}$, for each livestock type is calculated each day as:

$L_{w}=I_{l}+s_{l} \cdot T_{m}+S W_{l} \cdot D_{l}$

where

$I_{l}$ is an intercept parameter for livestock type $l$

$s_{l}$ is a slope parameter for livestock type $l[-]$

$T_{m}$ is the daily mean temperature, with a minimum value of $0\left[{ }^{\circ} \mathrm{C}\right]$

$S W_{l}$ is the daily service water volume required per animal

$D_{l}$ is the density of livestock type $l$ in the grid cell.

Livestock types represented are: buffalo, cattle, goats, pigs, poultry, and sheep.

\section{Water supply}

Input data

To simulate water supply, WBM requires inputs to represent rivers, reservoirs on those rivers, and the water budget of non-agricultural lands (including impervious areas). The river data is the STN-30p river network (Vörösmarty et al., 2000), and reservoir and dam inputs are from the GRanD database (Lehner et al., 2011). Soil properties of non-agricultural lands are from the Harmonized World Soil Database v1.1 (FAO/IIASA/ISRIC/ISSCAS/JRC, 2009), and impervious surface data is from the Global Distribution and Density of Constructed Impervious Surfaces database (Elvidge et al., 2007).

\section{Method}

Water supply is the sum of surface water (including reservoir storage) and renewable groundwater sources. Renewable groundwater is defined as the volume of water stored via 
percolation through soils, minus the volume of water exiting the groundwater stores as baseflow. Details for surface water and renewable groundwater methods are provided in Wisser et al (2010) and Grogan (2016).

\section{A3. Australian water market results}

At the suggestion of a referee, we estimated the basic asset pricing model (shown in equation (1)) using Australian water market transaction data.

$p^{\text {sale }}=\boldsymbol{p}^{\text {lease }} / \boldsymbol{r}$

Our empirical approach adapts equation (4) from the paper. Specifically, $\boldsymbol{l n} \boldsymbol{p}_{\boldsymbol{i j q} \boldsymbol{t}}=\boldsymbol{\gamma}_{\mathbf{0}}+$ $\boldsymbol{\gamma}_{1} \boldsymbol{l n} \pi_{i j q t}+\gamma_{2} \boldsymbol{r}_{q t}+\mu_{t}+\boldsymbol{\alpha}_{j}+\boldsymbol{\varepsilon}_{i j q t}$, where $\ln \boldsymbol{p}$ is the log price of entitlement transfer $i$ (similar to permanent water rights transfer in the U.S.), in state $\boldsymbol{j}$, in quarter $\boldsymbol{q}$, and in year $\boldsymbol{t}$; $\boldsymbol{l n} \boldsymbol{\pi}$ is the log price allocation transfer (similar to one year lease in the U.S.); $\boldsymbol{r}$ is the quarterly real Australian market interest rate; $\mu$ is a year fixed effect; $\boldsymbol{\alpha}$ is a state fixed effect or random effect; and $\varepsilon$ is the error term. Note that we omit the growth rate and risk premium variables, lacking available data for this extra analysis outside of the United States, the site of our main analysis.

The Australian water transaction dataset was downloaded from the Australian Government Bureau of Meteorology. We obtained allocation and entitlement transfers from 2007-2018 for five states for which both transfer type data were available: New South Wales, South Australia, Tasmania, Victoria, and Western Australia. Similar to our approach for the U.S. markets, we omitted observations that lacked price information, were associated with bundled water and land transfers, or were described as temporary entitlement transfers.

Transaction prices $(\$ / M L)$ were converted to 2009 Australian dollars using the consumer price index (CPI) obtained from the Australian Bureau of Statistics. The real interest rate was 
calculated by using Australian 90-day T-bill rate available via the Organization for Economic Co-operation and Development (OECD), and adjusting for inflation using CPI - similar to the U.S. models reported in the paper. The final quarterly averaged dataset comprised 165 observations.

Table A5 provides the results using two models: fixed effects (1), and random effects (2). Results using both approaches yield the expected coefficient signs: entitlement transfer prices are positively correlated with allocation transfer prices, and negatively correlated with real interest rates. Like our U.S. results, these results for Australia are consistent with asset pricing theory. However, given limits to data availability, we do not directly compare these results to those in the paper. A complete application of the asset pricing model to the Australian water market case would be an important extension of our analysis of the western U.S. water markets, and an excellent topic for further research.

\section{APPENDIX REFERENCES}

Allen RG, Pereira LS, Raes D, and Smith M. 1998. Crop evapotranspiration: Guidelines for computing crop water requirements. FAO irrigation and Drainage Paper No. 56. http://www.fao.org/3/X0490E/X0490E00.htm.

Australian Bureau of Statistics. 2019. Available at https://www.abs.gov.au/ (accessed August 14 2019).

Australian Government Bureau of Meteorology. 2019. Available at http://www.bom.gov.au/ water/dashboards/\#/water-markets/national/state/at (accessed August 2 2019).

Elvidge, C.D., Tuttle, B.T., Sutton, P.C., Baugh, K.E., Howard, A.T., Milesi, C., Bhaduri, B., Nemani, R. 2007. Global Distribution and Density of Constructed Impervious Surfaces. Sensors 7: 1962- 1979. doi:10.3390/s7091962. 
Food and Agriculture Organization (FAO). 2006. Livestock's Long Shadow: Environmental Issues and Options. http://www.fao.org/3/a0701e/a0701e.pdf.

FAO/IIASA/ISRIC/ISSCAS/JRC. 2009. Harmonized World Soil Database (version 1.1). FAO, Rome, Italy and IIASA, Laxenburg, Austria. URL: http://webarchive.iiasa.ac.at/Research/LUC/External-World-soil-database/HTML/.

Grogan, D.S. 2016. Global and regional assessments of unsustainable groundwater use in irrigated agriculture. UNIVERSITY OF NEW HAMPSHIRE. Doctoral Dissertations. 2. https://scholars.unh.edu/dissertation/2.

IIASA. 2007. Greenhouse gas initiative (GGI) scenario database.

Lehner, B., Liermann, C.R., Revenga, C., Vörösmarty, C., Fekete, B., Crouzet, P., Döll, P., Endejan, M., Frenken, K., Magome, J., Nilsson, C., Robertson, J.C., Rödel, R., Sindorf, N., Wisser, D. 2011. High-resolution mapping of the world's reservoirs and dams for sustainable river-flow management. Frontiers in Ecology and the Environment 9: 494502. doi:10.1890/100125.

Liu J., Hertel T., Lammers R., Prusevich A., Baldos U., Grogan D.S., Frolking, S. 2017. Achieving sustainable irrigation water withdrawals: Global impacts on food security and land use. Environmental Research Letters 12: 104009, doi:10.1088/1748-9326/aa88db.

Organization for Economic Co-operation and Development (OECD). 2019. 3-Month or 90-day Rates and Yields: Bank Bills for Australia retrieved from FRED, Federal Reserve Bank of St. Louis; https://fred.stlouisfed.org/series/IR3TBB01AUQ156N, August 14, 2019.

Portmann, F.T., Siebert, S., Döll, P. 2010. MIRCA2000_-Global monthly irrigated and rainfed crop areas around the year 2000: A new high-resolution data set for agricultural and hydrological modeling. Global Biogeochemical Cycles 24: GB1011. doi:10.1029/2008GB003435

Schmidt, G.A., M. Kelley, L. Nazarenko, R. Ruedy, G.L. Russell, I. Aleinov, M. Bauer, S.E. Bauer, M.K. Bhat, R. Bleck, V. Canuto, Y.-H. Chen, Y. Cheng, T.L. Clune, A. Del Genio, R. de Fainchtein, G. Faluvegi, J.E. Hansen, R.J. Healy, N.Y. Kiang, D. Koch, A.A. Lacis, A.N. LeGrande, J. Lerner, K.K. Lo, E.E. Matthews, S. Menon, R.L. Miller, V. Oinas, A.O. Oloso, J.P. Perlwitz, M.J. Puma, W.M. Putman, D. Rind, A. Romanou, Mki. Sato, D.T. Shindell, S. Sun, R.A. Syed, N. Tausnev, K. Tsigaridis, N. Unger, A. Voulgarakis, M.-S. Yao, and J. Zhang, 2014: Configuration and assessment of the GISS ModelE2 contributions to the CMIP5 archive. Journal of Advances in Modeling Earth Systems 6(1): 141-184, doi:10.1002/2013MS000265.

Siebert S., and Döll, P. 2010. Quantifying blue and green virtual water contents in global crop production as well as potential production losses without irrigation. Journal of Hydrology 384: 198-217, doi:10.1016/j.jhydrol.2009.07.031. 
Vörösmarty, C.J., Fekete, B.M., Meybeck, M., Lammers, R.B. 2000. Geomorphometric attributes of the global system of rivers at 30-minute spatial resolution. Journal of Hydrology 237: 17-39. doi:10.1016/S0022-1694(00)00282-1.

Wisser, D., Fekete, B.M., Vörösmarty, C.J., Schumann, A.H. 2010. Reconstructing 20th century global hydrography: a contribution to the Global Terrestrial Network- Hydrology (GTNH). Hydrology and Earth System Sciences 14: 1-24. doi:10.5194/hess-14-1-2010. 


\section{APPENDIX TABLES}

Table A1. Asset Pricing Model IV Estimation Results for the Multi-State Sample (Dependent variable: Log Transfer Price)

\begin{tabular}{|c|c|c|c|c|c|c|}
\hline & $\begin{array}{c}(1) \\
(9 \text { states })\end{array}$ & $\begin{array}{c}(2) \\
(9 \text { states })\end{array}$ & $\begin{array}{c}(3) \\
(9 \text { states })\end{array}$ & $\begin{array}{c}(4) \\
(3 \text { states })\end{array}$ & $\begin{array}{c}(5) \\
(3 \text { states })\end{array}$ & $\begin{array}{c}(6) \\
(3 \text { states })\end{array}$ \\
\hline Log lease price & $\begin{array}{l}0.009 \\
(0.543)\end{array}$ & $\begin{array}{l}0.007 \\
(0.596)\end{array}$ & $\begin{array}{l}0.224 \\
(0.283)\end{array}$ & $\begin{array}{l}0.134 \\
(0.434)\end{array}$ & $\begin{array}{l}0.134 \\
(0.554)\end{array}$ & $\begin{array}{l}0.308 \\
(0.226)\end{array}$ \\
\hline Growth rate: Acres irrigated & omitted & $\begin{array}{l}1.052 \\
(0.678)\end{array}$ & $\begin{array}{l}1.119^{* *} \\
(0.546)\end{array}$ & omitted & $\begin{array}{c}-1.643 * * * \\
(0.334)\end{array}$ & $\begin{array}{r}-2.496^{* * *} \\
(0.074)\end{array}$ \\
\hline $\begin{array}{l}\text { Risk premium: Irrigation } \\
\text { vulnerability index }\end{array}$ & omitted & $\begin{array}{c}0.046^{* * *} \\
(0.012)\end{array}$ & $\begin{array}{l}0.053 * * * \\
(0.010)\end{array}$ & omitted & $\begin{array}{l}1.470^{* * *} \\
(0.274)\end{array}$ & $\begin{array}{l}1.418^{* * *} \\
(0.162)\end{array}$ \\
\hline Real interest rate & $\begin{array}{c}-20.650^{* * *} \\
(6.650)\end{array}$ & $\begin{array}{c}-20.685^{* * *} \\
(7.253)\end{array}$ & $\begin{array}{l}-9.214 \\
(6.474)\end{array}$ & $\begin{array}{c}-22.821 * * * \\
(7.486)\end{array}$ & $\begin{array}{c}-22.821 * * \\
(9.543)\end{array}$ & $\begin{array}{l}-10.601 \\
(8.520)\end{array}$ \\
\hline Time trend & 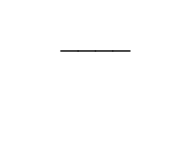 & 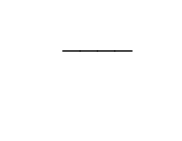 & $\begin{array}{c}0.069 * * * \\
(0.013)\end{array}$ & 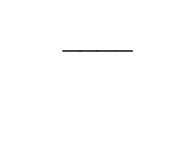 & 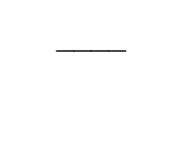 & $\begin{array}{l}0.069 * * * \\
(0.016)\end{array}$ \\
\hline State controls & $\mathrm{FE}$ & $\mathrm{RE}$ & $\mathrm{RE}$ & $\mathrm{FE}$ & $\mathrm{RE}$ & $\mathrm{RE}$ \\
\hline $\mathrm{N}$ (obs) & 66 & 66 & 66 & 53 & 53 & 53 \\
\hline $\mathrm{R}^{2}$ & 0.176 & 0.053 & 0.096 & 0.268 & 0.724 & 0.772 \\
\hline Cragg-Donald Wald F statistic & 3.404 & 3.683 & 3.670 & 3.789 & 3.789 & 3.702 \\
\hline $\begin{array}{l}\text { Kleibergen-Paap rk. Wald F } \\
\text { statistic }\end{array}$ & 3.614 & 3.735 & 3.744 & 2.742 & 2.580 & 2.659 \\
\hline $\begin{array}{l}p \text {-value of Kleibergen-Paap rk } \\
\text { LM statistic }\end{array}$ & 0.169 & 0.169 & 0.177 & 0.178 & 0.178 & 0.184 \\
\hline$p$-value of Endogeneity test & 0.705 & 0.707 & 0.910 & 0.972 & 0.981 & 0.613 \\
\hline
\end{tabular}


Table A2. Asset Pricing Model IV Estimation Results for the Mojave Market (Dependent variable: Log Transfer Price)

\begin{tabular}{|c|c|c|c|c|c|c|}
\hline & $\begin{array}{c}(1) \\
(5 \text { areas })\end{array}$ & $\begin{array}{c}(3) \\
\text { (5 areas) }\end{array}$ & $\begin{array}{c}(4) \\
(5 \text { areas })\end{array}$ & $\begin{array}{c}(5) \\
(2 \text { areas })\end{array}$ & $\begin{array}{c}(7) \\
(2 \text { areas })\end{array}$ & $\begin{array}{c}(8) \\
(2 \text { areas })\end{array}$ \\
\hline Log lease price (qtr.avg) & $\begin{array}{l}-4.391 \\
(5.533)\end{array}$ & $\begin{array}{l}0.056 \\
(0.850)\end{array}$ & $\begin{array}{l}-0.975 \\
(1.221)\end{array}$ & $\begin{array}{l}-139.074 \\
(14970.4)\end{array}$ & $\begin{array}{l}-139.074 \\
(21654.42)\end{array}$ & $\begin{array}{l}-1.439 \\
(2.879)\end{array}$ \\
\hline $\begin{array}{l}\text { Growth rate: Water } \\
\text { consumption }\end{array}$ & omitted & $\begin{array}{l}1.989 \\
(1.301)\end{array}$ & $\begin{array}{l}2.914^{* *} \\
(1.442)\end{array}$ & omitted & $\begin{array}{c}699.337 \\
(107992.7)\end{array}$ & $\begin{array}{l}7.288 \\
(7.125)\end{array}$ \\
\hline $\begin{array}{l}\text { Risk premium: Irrigation } \\
\text { vulnerability index }\end{array}$ & omitted & $\begin{array}{l}-0.063 \\
(0.083)\end{array}$ & $\begin{array}{l}-0.056 \\
(0.058)\end{array}$ & omitted & omitted & omitted \\
\hline Real interest rate & $\begin{array}{l}-133.234 \\
(177.974)\end{array}$ & $\begin{array}{l}-22.906 \\
(20.906)\end{array}$ & $\begin{array}{l}-3.883 \\
(8.775)\end{array}$ & $\begin{array}{l}-4023.65 \\
(431487.0)\end{array}$ & $\begin{array}{l}-4023.65 \\
(624138.1)\end{array}$ & $\begin{array}{l}-9.847 \\
(17.927)\end{array}$ \\
\hline Yearly trend & - & 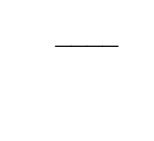 & $\begin{array}{l}0.111^{*} \\
(0.057)\end{array}$ & - & - & $\begin{array}{l}0.126 \\
(0.161)\end{array}$ \\
\hline Subarea controls & FE & $\mathrm{RE}$ & $\mathrm{RE}$ & $\mathrm{FE}$ & $\mathrm{RE}$ & $\mathrm{RE}$ \\
\hline $\mathrm{N}$ (obs) & 89 & 89 & 89 & 69 & 69 & 69 \\
\hline $\mathrm{R}^{2}$ & -21.405 & 0.552 & 0.528 & -14000 & 0.147 & 0.704 \\
\hline Cragg-Donald Wald F statistic & 0.593 & 11.538 & 5.238 & 0.000 & 0.000 & 4.240 \\
\hline $\begin{array}{l}\text { Kleibergen-Paap rk. Wald F } \\
\text { statistic }\end{array}$ & 0.566 & 3.356 & 2.278 & 0.000 & 0.000 & 0.437 \\
\hline $\begin{array}{l}p \text {-value of Kleibergen-Paap rk } \\
\text { LM statistic }\end{array}$ & 0.498 & 0.141 & 0.224 & 0.993 & 0.993 & 0.530 \\
\hline$p$-value of Endogeneity test & 0.396 & 0.131 & 0.131 & 0.771 & 0.000 & 0.000 \\
\hline
\end{tabular}


Table A3. Robustness Check: Asset Pricing Model Results for the Nine-State Sample with Different Growth Rate Proxy (Dependent Variable: Log Transfer Price)

\begin{tabular}{|c|c|c|c|c|c|c|}
\hline & $\begin{array}{c}(1) \\
\text { (9 states) }\end{array}$ & $\begin{array}{c}(2) \\
(9 \text { states })\end{array}$ & $\begin{array}{c}(3) \\
\text { (9 states) }\end{array}$ & $\begin{array}{c}(4) \\
(3 \text { states })\end{array}$ & $\begin{array}{c}(5) \\
(3 \text { states })\end{array}$ & $\begin{array}{c}(6) \\
(3 \text { states })\end{array}$ \\
\hline Log lease price & $\begin{array}{l}0.154 * \\
(0.070)\end{array}$ & $\begin{array}{l}0.162 * * \\
(0.072)\end{array}$ & $\begin{array}{c}0.166^{* * *} \\
(0.061)\end{array}$ & $\begin{array}{c}0.146 \\
(0.071)\end{array}$ & $\begin{array}{l}0.146^{* *} \\
(0.072)\end{array}$ & $\begin{array}{l}0.153 * * \\
(0.063)\end{array}$ \\
\hline Growth rate: Irrigated crop price & $\underline{-}$ & $\begin{array}{r}1.215 \\
(2.740)\end{array}$ & $\begin{array}{r}0.754 \\
(2.732)\end{array}$ & $\longrightarrow$ & $\begin{array}{c}-6.847 * * * \\
(0.255)\end{array}$ & $\begin{array}{c}-9.940 * * * \\
(0.585)\end{array}$ \\
\hline $\begin{array}{l}\text { Risk premium: Irrigation } \\
\text { vulnerability index }\end{array}$ & 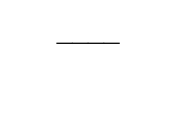 & $\begin{array}{c}0.042 * * * \\
(0.014)\end{array}$ & $\begin{array}{c}0.047 * * * \\
(0.015)\end{array}$ & - & $\begin{array}{c}1.523 * * * \\
(0.071)\end{array}$ & $\begin{array}{c}1.417 * * * \\
(0.089)\end{array}$ \\
\hline Real interest rate & $\begin{array}{c}-20.061^{* *} \\
(7.320)\end{array}$ & $\begin{array}{c}-20.026 * * * \\
(7.440)\end{array}$ & $\begin{array}{l}-9.341 \\
(6.534)\end{array}$ & $\begin{array}{l}-22.767 \\
(8.306)\end{array}$ & $\begin{array}{c}-22.767 * * * \\
(8.477)\end{array}$ & $\begin{array}{l}-11.437 \\
(7.851)\end{array}$ \\
\hline Time trend & - & 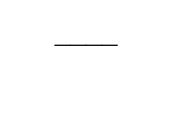 & $\begin{array}{c}0.070 * * * \\
(0.013)\end{array}$ & $\underline{-}$ & $\underline{-}$ & $\begin{array}{c}0.068 * * * \\
(0.017)\end{array}$ \\
\hline State controls & $\mathrm{FE}$ & $\mathrm{RE}$ & $\mathrm{RE}$ & $\mathrm{FE}$ & $\mathrm{RE}$ & $\mathrm{RE}$ \\
\hline$\overline{\mathrm{N}}$ (obs) & 66 & 66 & 66 & 53 & 53 & 53 \\
\hline $\mathrm{R}^{2}$ & 0.212 & 0.154 & 0.199 & 0.269 & 0.724 & 0.788 \\
\hline
\end{tabular}

Note: $* * *$ Significance at $1 \%, * *$ Significance at $5 \%,{ }^{*}$ Significance at $10 \%$; values in parentheses are robust standard errors clustered by state. All models include a constant. Growth rate proxy in this model is constructed for each state based on prices of the type of crop which uses a significant amount of irrigation water in its production. The major crops were determined based on analyzing the values for irrigated area harvested, irrigated crop/acre yield, and average AF of water applied for acre provided in the USDA Water Management and Irrigation Survey. Specifically, we used annual prices from 1990-2018 available at USDA for alfalfa (AZ), corn (CO, NM, TX, WA), rice (CA), and wheat (ID, NV, UT), and constructed the time invariant growth rate variable using the AR(1) approach (where we included the natural log of water price, year, and a constant). 
Table A4: Average long-term Irrigation Vulnerability Index by state

\begin{tabular}{cc}
\hline State & Irrigation Vulnerability Index \\
\hline Arizona & -2.408 \\
California & -1.325 \\
Colorado & -0.101 \\
Idaho & 0.501 \\
Nevada & 59.465 \\
New Mexico & 2.253 \\
Texas & -1.021 \\
Utah & 4.326 \\
Washington & 1.650 \\
\hline
\end{tabular}

Table A5: Asset Pricing Model Estimation Results for Australian Water Transfers, 20072018 (Dependent Variable: Log Entitlement Transfer Price)

\begin{tabular}{lcc}
\hline & $(1)$ & $(2)$ \\
& $(5$ states $)$ & $(5$ states $)$ \\
\hline Log lease price & 0.026 & $0.225^{* * *}$ \\
& $(0.046)$ & $(0.076)$ \\
Real interest rate & -10.298 & -10.008 \\
Year Controls & $(10.613)$ & $(11.772)$ \\
State Controls & Yes & Yes \\
& FE & RE \\
N (obs) & & 165 \\
$\mathrm{R}^{2}$ & 165 & 0.223 \\
\hline
\end{tabular}

Note: $* * *$ Significance at $1 \%, * *$ Significance at $5 \%, *$ Significance at $10 \%$; values in parentheses are standard errors clustered by state, which have been corrected for heteroskedasticity. All models include a constant. Observations are from five states: New South Wales, South Australia, Tasmania, Victoria, and Western Australia. 